\title{
Sugarcane Borer, Diatraea saccharalis (Fabricius) (Insecta: Lepidoptera: Pyralidae) ${ }^{1}$
}

John L. Capinera²

\section{Distribution}

The sugarcane borer, Diatraea saccharalis (Fabricius), is native to the western hemisphere, but not to the United States. It apparently was introduced into Louisiana about 1855, and has since spread to the other Gulf Coast States. It inhabits only the warmer portions of these states, however. Sugarcane borer also occurs throughout the Caribbean, Central America, and the warmer portions of South America south to northern Argentina.

\section{Life Cyle and Description}

Overwintering occurs in the larval stage, with pupation in the spring. In Louisiana and Texas, adults become active by April or May, and the borer population continues to cycle until autumn. Development time is highly variable, so the generations overlap considerably, obscuring population trends. There is potential for four to five generations to occur annually, but moths are abundant only in spring and autumn (Fuchs and Harding 1979), so perhaps there are fewer generations. During the summer a complete generation may require only 25 days whereas during the winter over 200 days are needed.

\section{Eggs}

The eggs are flattened and oval in shape, measuring about $1.16 \mathrm{~mm}$ in length and $0.75 \mathrm{~mm}$ in width. They are deposited in clusters, and overlap like the scales on a fish. An egg cluster may contain from two to 50 eggs, with eggs deposited on both the upper and lower surface of leaves. The eggs are white initially, but turn orange with age and then acquire a blackish hue just before hatching. Duration of the egg stage is four to six days. Mean fecundity is about 700 eggs when borers are reared on corn and sugarcane, but only about 425 when fed Johnsongrass (Bessin and Reagan 1990).

\section{Larvae}

Eggs within a cluster hatch about the same time, or at least within a few hours of one another. Larvae tend to congregate in the whorl of corn plants and begin feeding almost immediately. They may feed through the leaf tissue or tunnel through the midrib. After the first or second molt they burrow into the

1. This document is EENY-217, one of a series of Featured Creatures from the Entomology and Nematology Department, Florida Cooperative Extension Service, Institute of Food and Agricultural Sciences, University of Florida. Published: July 2001. This document is also available on Featured Creatures Website at http://creatures.ifas.ufl.edu. Please visit the EDIS Website at http://edis.ifas.ufl.edu. Additional information on these organisms, including many color photographs, is available at the Entomology and Nematology Department Website at http://entnemdept.ifas.ufl.edu/. 2. John L. Capinera, department chairman/professor, Entomology and Nematology Department, University of Florida, Gainesville, FL.

The Institute of Food and Agricultural Sciences (IFAS) is an Equal Employment Opportunity - Affirmative Action Employer authorized to provide research, educational information and other services only to individuals and institutions that function without regard to race, creed, color, religion, age, disability, sex, sexual orientation, marital status, national origin, political opinions or affiliations. For information on obtaining other extension publications, contact your county Cooperative Extension Service office. Florida Cooperative Extension Service / Institute of Food and Agricultural Sciences / University of Florida / Larry R. Arrington, Interim Dean 
stalk. The larvae display both summer and winter forms. The larvae are whitish with a brown head, but the summer form also bears large brown spots on each body segment whereas the winter form lacks spots. A stout hair originates in each of the spots, or in the case of the winter form, from the location where the spot might appear. Larvae during the winter are rarely found in corn; sugarcane and stalks of large grasses are more suitable and preferred. Instar number is quite variable. There are reports of three to 10 instars, but five to six is normal. Holloway et al. (1928) reported instar duration of about 3-6, 4-8, 6-9, 4-6, and 4-9 days for instars one through five, respectively, for larvae fed sugarcane. When reared on artificial diets, most larvae tend to display six instars. Roe et al. (1982) reported mean head capsule widths of about $0.29,0.40,0.62,0.93$, and $1.32 \mathrm{~mm}$ for instars one through five in larvae that had six instars; head capsule measurements were not reported for the final instar but probably were about $1.75 \mathrm{~mm}$. Larval development time usually requires 25 to 30 days during warm weather and 30 to 35 days during cool weather except, of course, during the winter when development is arrested. Larvae attain a length of about 2-4, 6-9, 10-15, 15-20, 20-30 mm during instars one through five, respectively. Larvae of sugarcane borer are easily confused with southern cornstalk borer, and definitive separation involves microscopic examination of the mouthparts.

Sugarcane borer, however, is much less likely than southern cornstalk borer, Diatraea crambidoides (Grote), to be found infesting corn.

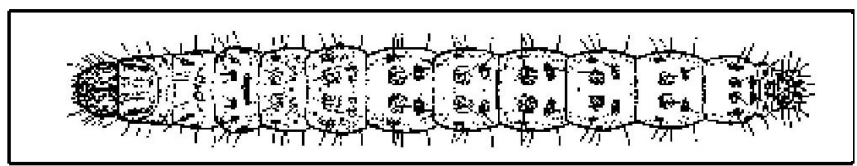

Figure 1. Larva (head on left). Credits: William White, USDA

\section{Pupae}

Pupation occurs within the plant, in a tunnel created by the larva. The larva cleans and expands the tunnel prior to pupation, leaving only a thin layer of plant tissue for the moth to break through at emergence. The pupa is elongate and slender, and yellowish brown to mahogany brown in color. It measures 16 to $20 \mathrm{~mm}$ in length and bears prominent pointed tubercles on the distal segments. Duration of

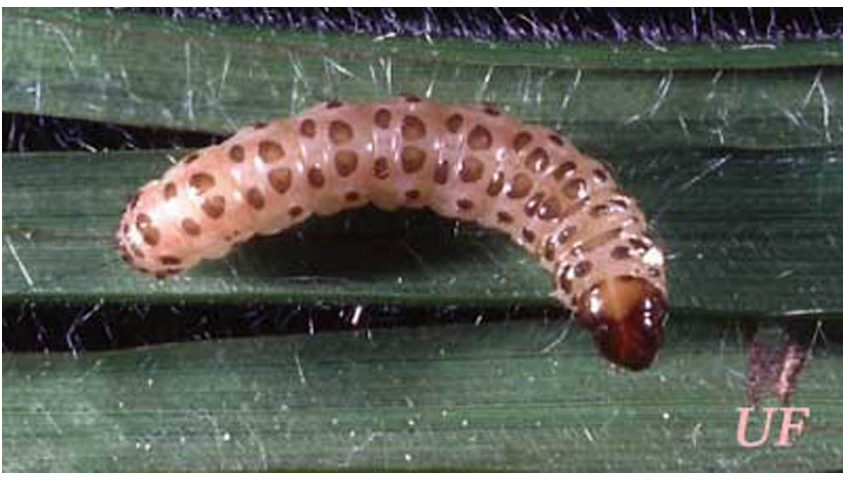

Figure 2. Larva of the sugarcane borer, Diatraea saccharalis (Fabricius). Credits: John Capinera, University of Florida

the pupal stage is usually eight to nine days, but under cool conditions may extend for up to 22 days.

\section{Adults}

The adult is a yellowish or yellowish brown moth with a wing span that measures 18 to $28 \mathrm{~mm}$ in males and 27 to $39 \mathrm{~mm}$ in females. The forewing also bears numerous narrow brown lines extending the length of the wing. The hind wing of females is white, but in males it is darker. The adults are nocturnal, remaining hidden during the daylight hours. Oviposition commences at dusk and continues throughout the evening. Females may deposit eggs for up to four days, but often less. Duration of the adult stage is three to eight days.

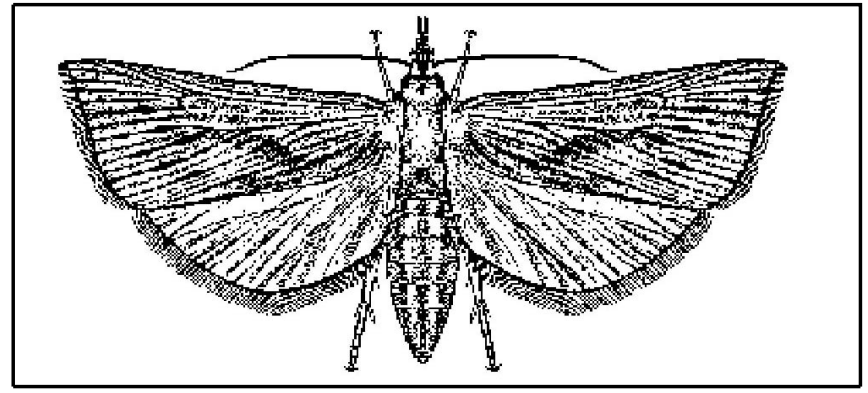

Figure 3. Adult.

Biology of sugarcane borer is described by Holloway et al. (1928) and a bibliography was authored by Roe (1981). Several wheat germ-based diets are suitable for rearing (Roe et al. 1982). A key to Diatraea larvae can be found in Peterson (1948), and Stehr (1987), and to adults in Dyar and Heinrich (1927). A key to stalk borers associated with corn in southern states is presented by Dekle (1976); this publication also includes pictures of the adults. 


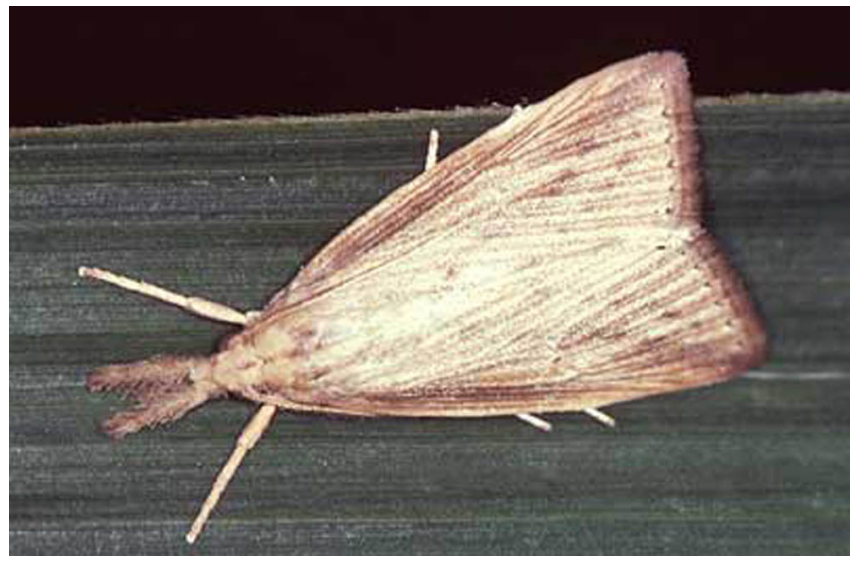

Figure 4. Adult sugarcane borer, Diatraea saccharalis (Fabricius). Credits: William White, USDA

\section{Damage}

Sugarcane borer sometimes is a serious pest of sugarcane. Larvae bore into the sugarcane stalks. In mature plants the tops tend to weaken or die, sometimes breaking off. In young plants the inner whorl of leaves is killed, resulting in a condition known as "dead heart." The amount and purity of juice that can be extracted from cane is reduced when borers are present, and sucrose yield may be decreased 10 to $20 \%$. Lastly, when seed cane is attacked, the tunneling by borers makes the seed piece susceptible to fungal infection.

Other crops are rarely at risk. Sugarcane borer is a minor pest of sweet corn even in Florida, where the weather favors its survival and sugarcane is abundant (Kelsheimer et al. 1950). Damage by sugarcane borer to grain corn is described by Flynn and Reagan (1984) and Flynn et al. (1984). Larvae injure corn in two ways. Early in the season they attack the whorl, feeding on the young developing tissue. If such damage is light the result may be only series of holes across the leaf blade. If such damage is extensive, however, the growing point of the plant may be killed and plant growth stunted. Later in the season the larvae descend to the stalk and burrow in. Large larvae tunnel through the stalk, causing the plant to be prone to breakage. On occasion, especially during the second generation, larvae may burrow into corn ears (Rodriguez- del-Bosque et al. 1990).

\section{Host Plants}

Sugarcane borer attacks plants in the family Gramineae (grasses). Though principally a pest of sugarcane, this insect also will feed on other crops such as corn, rice, sorghum, and sudangrass. Many wild or weed grasses are suitable hosts, including Johnsongrass, Sorghum halepense; Paspalum sp.; Panicum spp.; Holcus sp.; and Adropogon sp.

\section{Natural Enemies}

The importance of natural enemies is known principally in sugarcane, its major host. Ants, particularly red imported fire ant, Solenopsis invicta Buren, are reported to be important predators of sugarcane borer in sugarcane fields, and capable of reducing damage from borers by over $90 \%$ (Bessin and Reagan 1993). Although much of the attention has been focused on red imported fire ant, other ant species such as Pheidole dentata Mayr and $P$. floridana Emery (all Hymenoptera: Formicidae) also are important (Adams et al. 1981).

Effective parasitoids are not established in the United States. Egg parasitoids, Trichogramma sp. (Hymenoptera: Trichogrammatidae), are possibly the most important naturally-occuring parasitic insects. Although they are not very abundant early in the season, by autumn they may inflict almost complete destruction of borer eggs. The most important imported parasitoid is Agathis stigmaterus (Cresson) (Hymenoptera: Braconidae), which was reported by King et al. (1981) to affect, on average, less than $12 \%$ of borers. Lixophaga diatraeae (Diptera: Tachinidae) has the potential to cause high levels of parasitism, but does not persist well (see biological control, below). A wasp introduced from India, Cotesia flavipes Cameron (Hymenoptera: Braconidae), is an important late-season parasitoid late in the summer within Florida. Other parasitoids include Orgilus elasmopalpi Muesebeck, Apanteles diatraeae Musebeck, Apanteles impunctatus Musebeck (all Hymenoptera: Braconidae), Euplectrus plathypenae Howard, and Syntomosphyrum clisiocampe (Ashmead) (both Hymenoptera: Eulophidae).

Fuller and Reagan (1988) studied the role of natural enemies in sugarcane and sorghum. Predator densities were higher in sugarcane due to the greater 
abundance of red imported fire ant. However, Orius spp. pirate bugs (Hemiptera: Anthocoridae), lacewings (Neuroptera: Chrysopidae), tiger beetles (Coleoptera: Cicindelidae), spiders, and foliage-dwelling ground beetle larvae (Coleoptera: Carabidae) were more abundant in sorghum fields. Application of soil insecticide affected predation in both agroecosystems, with borer populations 40 to $60 \%$ higher where predator abundance was reduced.

\section{Weather}

An inverse relationship between rainfall and borer abundance has been reported from both Louisiana and Puerto Rico. Heavy rainfall, and particularly winter rainfall resulting in flooding, depresses borer survival (Holloway et al. 1928). This is thought to result from prolonged emersion of stalks containing overwintering larvae in flood water. Also, young larvae living in the whorl of corn or sugarcane are quite tolerant of short-term emersion, but heavy rainfall while they are dispersing could lead to death because they are washed from the plants. In addition to rainfall, cold winter temperatures are reported to depress larval survival rates in Louisiana.

\section{Management}

\section{Sampling}

Larval distribution in sugarcane is described by Hall (1986), who determined that a sample of sugarcane consisting of five stalks taken from five plants spaced $3 \mathrm{~m}$ apart gave a good indication of borer density. Borer poulations were more aggregated at higher densities, and more difficult to estimate.

\section{Insecticides}

Insecticides can be applied to the foliage of sugarcane, providing significant yield increases even in the presence of predation and resistant varieties (Bessin et al. 1990). Insecticides should be applied while the larvae are young, before they burrow into the stalk. However, some control is possible even later, possibly because larvae leave their tunnel during the process of pushing out excrement.

For more information see the following:
- Insect Management Guide for Sugarcane (http://edis.ifas.ufl.edu/IG065)

- Insect Management Guide for Field Corn (http://edis.ifas.ufl.edu/IG060)

- Insect Management Guide for Sweet Corn (http://edis.ifas.ufl.edu/BODY_IG158)

\section{Cultural Practices}

It is advisable to destroy cane trash in the winter as it will reduce overwintering by larvae, but the practice of burning does not always kill borers deep within the stalks. borers can also overwinter in other crops and weeds, but sugarcane is the principal site. Some sugarcane cultivars display considerable resistance to sugarcane borer (Bessin et al. 1990, Bessin and Reagan 1993). Grain corn varieties with resistance to sugarcane borers also have been identified (Maredia and Mihm 1991).

\section{Biological Control}

The Caribbean region and tropical areas of South America have been surveyed extensively for natural enemies. Many species were introduced into the United States but few have established (Clausen 1978). Agathis stigmatera (Cresson) (Hymenoptera: Braconidae) was successfully imported from Argentina and Peru, and although it is well established in both Florida and Louisiana, its effect on sugarcane borer has been minimal. The fly Lixophaga diatraeae (Townsend) (Diptera: Tachinidae) was imported and released repeatedly, but tends to disappear or dissipate after a few years. In some countries, augmentative releases are used to attain high levels of parasitism in sugarcane borer, and this has been attempted in Louisiana (King et al. 1981). Some workers have claimed success with augmentative releases of Trichogramma spp. (Hymenoptera: Trichogrammatidae), but this has proven difficult to implement in the United States (Long and Hensley 1972).

\section{Selected References}

Adams CT, Summers TE, Lofgren CS, Focks DA, Prewitt JC. 1981. Interrelationship of ants and the sugarcane borer in Florida sugarcane fields. Environmental Entomology 10:415-418. 
Bessin RT, Reagan TE. 1990. Fecundity of sugarcane borer (Lepidoptera: Pyralidae), as affected by larval development on gramineous host plants. Environmental Entomology 19:635-639.

Bessin RT, Reagan TE. 1993. Cultivar resistance and arthropod predation of sugarcane borer (Lepidoptera: Pyralidae) affects incidence of deadhearts in Louisiana sugarcane. Journal of Economic Entomology 86:929-932.

Bessin RT, Moser EB, Reagan TE. 1990. Integration of control tactics for management of the sugarcane borer (Lepidoptera: Pyralidae) in Louisiana sugarcane. Journal of Economic Entomology 83:1563-1569.

Capinera JL. 2001. Handbook of Vegetable Pests. Academic Press, San Diego. 729 pp.

Clausen CP. 1978. Introduced Parasites and Predators of Arthropod Pests and Weeds: A World Review. USDA Agricultural Handbook 480. 545 pp.

Dekle GW. 1976. Illustrated key to caterpillars on corn. Florida Department of Agriculture and Consumer Services Division of Plant Industry Bulletin 4. 16 pp.

Dyar HG, Heinrich C. 1927. The American moths of the genus Diatraea and allies. Proceedings of the U.S. Natural Museum 71:1-48.

Flynn JL, Reagan TE. 1984. Corn phenology in relation to natural and simulated infestations of the sugarcane borer (Lepidoptera: Pyralidae). Journal of Economic Entomology 77:1524-1529.

Flynn JL, Reagan TE, Ogunwolu EO. 1984. Establishment and damage of the sugarcane borer (Lepidoptera: Pyralidae) in corn as influenced by plant development. Journal of Economic Entomology 77:691-697.

Fuchs TW, Harding JA. 1979. Seasonal abundance of the sugarcane borer, Diatraea saccharalis, on sugarcane and other hosts in the lower Rio Grande Valley of Texas. Southwestern Entomologist 4:125-131.
Fuller BW, Reagan TE. 1988. Comparative predation of the sugarcane borer (Lepidoptera: Pyralidae) on sweet sorghum and sugarcane. Journal of Economic Entomology 81:713-717.

Hall DG. 1986. Sampling for the sugarcane borer (Lepidoptera: Pyralidae) in sugarcane. Journal of Economic Entomology 79:813-816.

Holloway TE, Haley WE, Loftin UC, Heinrich C. 1928. The sugar-cane borer in the United States. USDA Technical Bulletin 41. 77 pp.

Kelsheimer EG, Hayslip NC, Wilson JW. 1950. Control of budworms, earworms and other insects attacking sweet corn and green corn in Florida. Florida Agriculture Experiment Station Bulletin 466. $38 \mathrm{pp}$.

Long WH, Hensley SD. 1972. Insect pests of sugar cane. Annual Review of Entomology 17:149-176.

Maredia KM, Mihm JA. 1991. Sugarcane borer (Lepidoptera: Pyralidae) damage to maize at four plant growth stages. Environmental Entomology 20:1019-1023.

Peterson A. 1948. Larvae of Insects, an Introduction to Nearctic Species. Part I Lepidoptera and Plant Infesting Hymenoptera. Edwards Brothers, Inc., Ann Arbor. 315 pp.

Rodriguez-del-Bosque LA, Smith Jr JW, Browning HW. 1990. Feeding and pupation sites of Diatraea lineolata, D. saccharalis, and Eoreuma loftini (Lepidoptera: Pyralidae) in relation to corn phenology. Journal of Economic Entomology 83:850-855.

Roe RM. 1981. A bibliography of the sugarcane borer, Diatraea saccharalis (Fabricius), 1887- 1980. USDA, ARS. ARM-S 20. 101 pp.

Roe RM, Hammond Jr AM, Sparks TC. 1982. Growth of larval Diatraea saccharalis (Lepidoptera: Pyralidae) on an artificial diet and synchronization of the last larval stadium. Annals of the Entomological Society of America 75:421-429.

Stehr FW. (ed.). 1987. Immature Insects. Vol. 1. Kendall/Hunt Publ. Co., Dubuque. 754 pp. 